ISSN (print): 2706- 6908, ISSN (online): 2706-6894

Vol.15 No.2 June 2020

\title{
Analysis of the economic and social conditions of the displaced in Iraq for the period 2014-2015
}

\author{
Ass.Lecturer : Sabiha Neama Dhahad \\ Southern Technical University - Technical Institute in Nasiriyah \\ sabihand@stu.edu.iq
}

https://doi.org/10.32792/utq/utj/vol15/2/5

\begin{abstract}
The research aims to identify the plight of internally displaced persons in Iraq and to highlight the size of the study of the causes and effects social and economic for displaced people and try to formulate Strategy proposed to contain the phenomenon of displacement through a survey the views of a sample composed of 78 individuals who have informed this phenomenon and through the national survey data for the displaced accomplished by the Central Bureau of Statistics and the data obtained from the matrix trace of Displaced, which is the information tool of the international Organization for migration )international organization for migration ( for the period from January 2014 until April 2015 it was to display this data tables statistically to get to the results of the study.The results show That the internal displacement problem is one of the most dangerous phenomena in Iraqi society and the danger is to increase the flow and continuity and lack of control of the containment, the study many of the most important results showed that internal displacement in Iraq, a collective phenomenon that do not fit a particular age group and both sexes were born displacement great suffering for displaced people, including political and security healthy and economical ... etc., the researcher provided a set of recommendations , the most important of the formation of an emergency body permanent for all
\end{abstract}


crises and disasters are expected to occur in the state and the crisis is not a temporary cell.

Key words: the suffering of the displaced, displacement, migration, displacement treatment.

\section{Introduction}

It became the internal phenomenon of displacement in Iraq of the big problems faced by the state for a large segment of Iraqis generating reality bad too in the areas of economic, security, health and political, were adopted study on the $\hat{A}$ behind a group of individuals obtained numbers form Questionnaire form he prepared for this purpose and also on a national survey of displaced people It was carried out by the Ministry of Planning in cooperation with the Ministry of Immigration and Displacement, and one of the obstacles to this survey is its implementation in emergency circumstances that are unusual, receptive and mobile due to the fluctuation of the security situation, or that there is a continuation of the displacement process and confuse the real numbers of displaced persons. The problem of the displaced in general and the displaced in Iraq in particular has been defined and its main causes, presenting the features of internal displacement in Iraq, determining its size, analyzing economic and social problems in a way that serves decision-makers and policymakers, and trying to contain the phenomenon of internal displacement in Iraq or limit the size of the damage caused to families as a result of displacement . The first study is the research methodology, the second study is the theoretical side, previous studies, and the third study is the interpretation of the research results, then the conclusions and recommendations .

\section{The first topic}

\section{Research Methodology}




\section{Research problem}

The problem with research in the emergence of the phenomenon of internal displacement in Iraq, which led to the emergence of many of the problems

of this segment of the society and it summarized Almhk for its following questions:

1- What is displacement, and what are its causes?

2- What are the economic ,social ,health, environmental, educational and political impacts on the displaced?

3- What initiatives did the state and relevant organizations offer for the displaced?

4- What are the possible solutions to contain this crisis?

Study hypotheses:

1- Internal displacement in Iraq came for political and sectarian reasons .

2- Not containing the displacement crisis in Iraq due to the weak role of the relevant authorities

\section{Research importance}

After the recent events, Iraq witnessed the phenomenon of internal displacement, and the importance of research stems from analyzing the economic and social conditions of this segment of society in a way that serves decision-makers and policy-makers, as well as the role of research in providing some recommendations to contain the phenomenon of internal displacement in Iraq or to limit the extent of damage to families from By displacement .

\section{The method of work-:}

This study relied in determining the magnitude of the phenomenon and its effects on the survey of a national IDP, which was prepared by 
the Central Bureau of Statistics as well as the form of the questionnaire ,which were adopted by the researcher was implemented in emergency conditions and unusually volatile and moving related to the security situation and the current crisis that there is continuing displacement And confusion about the real numbers of displaced people. The causes of the

phenomenon were examined by studying the views of a group of individuals.

\section{research aims}

1-Definition of displacement and its basic causes.

2-Identify the suffering of the displaced.

3- Displaying the features of displacement and highlighting its size through the results of the 2014 national survey of internally displaced Iraqis.

4- Study the social and economic impacts of the displaced by identifying the cases (health, education, workforce, family level, protection of rights, type and size of damage to families as a result of displacement )

5- Attempting to formulate a proposed strategy to contain the phenomenon of displacement

\section{Search tool}

The study represented a tool form for Questionnaire form that consists of (20) within a paragraph scale Likert quintet distributed on four axes in addition to the scientific qualification and workplace interrogators and his $\mathrm{J}$ :

1 - Reasons and its number (4) paragraphs

2-Containing the crisis and the role of the concerned authorities, which are

(6) paragraphs

3- The effects of the crisis, their number(5) 
4- Means of treatment or mitigation of the crisis (5 )paragraphs

Offered the questionnaire on the number of arbitrators specialists in each of the measurement and evaluation were also presented to the professors specialized in the science of specialized statistics set out their names and scientific titles in Appendix (1) so as to ensure the accuracy and the drafting of the paragraphs of the questionnaire and the validity of paragraphs used and the clarity of its elements and terminology has resulted in arbitration for re Arrangement ,cancellation, amendment ,addition and Appendix No. (2)

clarifies the outcome of that arbitration process.As the form became composed of (20) paragraphs, after making the required amendments to it.

\section{Stability test}

The Adopting the retail mid - term method for measuring the stability of the scale as a way shorten the time and fit with the nature of the study data segmenting paragraphs of the questionnaire into two groups (questions Vzdih and marital questions) and conduct test consistency among them was based on an equation Spearman Brown and predictable factor of stability of any test if we know coefficient for Stability of half or any part of it .If we divide any test into two equivalent parts, then calculate the correlation coefficient of the two parts ( R)We can use the prediction factor of Spearman Brown to know the total test according to the following equation : ${ }^{(18)}$

Coefficient of Reliability $=2 * \mathrm{R} /(1+\mathrm{R}), \quad \mathrm{R}=0.73 \quad$, Coefficient of Reliability $=0.84$

\section{Research Methodology}

Descriptive method approach case study was used of internally displaced Iraqis, adopted the research method of analysis of conclusion to 
reach the modest results and recommendations from the reality of the information obtained through the search tool provided for the study. And through the results of the comprehensive survey that was conducted by the Ministry of Planning and the Ministry of Immigration and Displacement.

\section{The research sample}

To investigate the causes and effects of the phenomenon was designed Form Questionnaire distributed to 80 individuals who have a shared interest in this phenomenon of individuals working in the Ministry of Displacement and Migration and workers in organizations, religious bodies, journalists, lawyers and university professors selected random

sample stratified manner, retrieved them (78) Form .The survey also views sample research members consisting of (78) individuals were selected random sample stratified manner

\section{search limits}

Spatial:and Temporal: all Iraqi governorates (except Anbar, Naynawa and Salah al-Din), 2014 AD

\section{The second topic}

\section{The theoretical side and previous studies}

\section{The first topic :scientific concepts and terminology for research Preface}

Wars have serious implications seriously and the results of bad not confined only to the dead and wounded and disabled, but include refugees Wa for displaced and displaced from their places of residence as suddenly 
turning from citizens Â Menen to displaced people in various other places in need of care, safe haven and stability, as well as their need for other humanitarian services, The phenomenon of asylum and displacement results from wars and international or internal conflicts alike.

\section{1 - 1 : Definition of displacement:}

It is a situation in which a person finds himself forced to leave his original home and move to another place in search of safety and protection.

\section{Also Displaced was defined as $:^{(16)}$}

$\mathrm{He}$ is a person whose property and life have been threatened by conflicts and internal wars, violation of his human rights, or due to natural disasters . Therefore, this definition does not include immigrant persons who leave their areas voluntarily and by choice, and for economic and social reasons.

\section{1 - 3 : Definition of internal displacement:}

Internally displaced persons are individuals or groups who have been forced or compelled to flee and leave their homes and areas of residence, as a result of or with the aim of avoiding the effects of armed conflicts, situations of widespread violence, violations of human rights or natural or human disasters, and those displaced have not crossed recognized international borders.

The components of the Definition of internally displaced : ${ }^{(13)}$

The definition developed by the International Guiding Principles of Internal Displacement focuses on two elements:

First, the nature of the transition of coercive or non - voluntary in any form, mentions the definition of some months, the causes of the transition forced, such as armed violence, conflict and violations 
of human rights and disasters share these causes in a common element, is that people for does not leave them with no choice but to leave their homes and they are deprived of the most basic protection mechanisms Such as social networks, access to services, and ways to earn a living.Displacement has a major impact on the physical,economic ,social and legal integrity of people and should be used as an indicator of their potential harm.

Second : This transfer is within the national borders. Internally displaced persons remain under the legal guardianship of the authorities of the state of their permanent residence, and therefore they enjoy the same rights as the rest of the people. The guidelines on internal displacement remind the national authorities and other concerned parties of their responsibility to ensure respect and fulfillment of the rights of the displaced despite the bad conditions. Which they fall under due to displacement.

There are many definitions of displacement ${ }^{(13)}$

- have known refugees COR

"That he is a citizen who was forced to move from his original home to another place inside the country".

-The definition of Human Rights of the United Nations

"A person or group of people forced to leave their homes or areas of their usual residence with the aim of moving away from places of armed conflict and usurpation of general human rights or natural or humanitarian disasters and did not cross the borders of their internationally known country."

- The United Nations High Commissioner for Refugees define them : 
"That they are individuals who live close to the refugees and have been forcibly displaced".

-The displaced was defined :"Persons or groups who were forced to flee or leave their homes or places of habitual residence in particular as a result of the following or in order to avoid : the effects of armed conflict, generalized violence, violations of human rights and man-made disasters .And those who did not cross the borders of the internationally recognized state " (14)

The researcher believes that it is possible to define (displacement, displaced) persons,Displacement: It is a phenomenon that the person himself creates by creating conditions that cause the loss of will for a group of people, which causes them to leave their places and search for safe and stable places for them .

Displaced people: people who were forced to leave their homes and areas due to the violation of their human rights.

\section{$1-4$ : The concept of displacement:}

Is one of the forms only transition geographical populations occur in many parts of the world and no reasons different, on it displacement

of compulsory ( forced or involuntary ) of

the population individually or groups natural causes residency Temporary or permanent (13)

Since the topic of our research revolves around displacement, we deem it necessary to clarify the difference between it and migration

Migration: is the movement of an individual or human group from one place to another based on a decision made under the influence of one or more of the factors leading to it.Migration, regardless of its type and current, depends in general on a set of push or pull factors that can be determined by 
economic, social, demographic ,geographic, psychological, personal, natural and environmental factors ${ }^{(12)}$

\section{1 - 5 : Types of displacement : ${ }^{(9)}$}

It can be divided at the level of geographical transmission into two types:

1- External displacement means the movement of displaced persons and the passing of international borders and occurs when the population presence felt oppression and inequality or presse on his freedom in one way or another or to chase him because of his discovery of certain ideas and perhaps to be expected to occur as a result of changing the system of government in his country .hdt in 1980 where they were displaced Kurds Faili To Iran .And the displacement of the Kurds of Kurdistan to the central and southern regions of Iraq .After 2003, forced migration occurred in a large scale, reaching about (250.000) were displaced outside Iraq.

2- Internal Displacement : a field of study in this research as a result of manifestations of violence occur and persecution of sectarian diversity in countries with ethnic, ethnic and religious. It is one of the most dangerous types of immigration because of the great economic ,demographic

and social consequences that arise on its basis, not limited to the area of origin, but even to the region of arrival

\section{Displacement characteristics : ${ }^{(9)}$}

1- A mass migration of all age groups.

2- Forced immigration occurs due to circumstances beyond human control, such as violence and sectarian discrimination. 


\section{3- irregular}

Since the topic of our research revolves around displacement, we deem it necessary to clarify the difference between it and migration

Migration: is the movement of an individual or human group from one place to another based on a decision made under the influence of one or more of the factors leading to it. Migration, whatever its type and current, generally depends on a set of push or pull factors that can be determined by economic, social, demographic, geographic, psychological, personal, natural and environmental factors ., *It is the movement of the population or their movement across international borders, as it is known as external migration to distinguish between it and internal migration that is within the borders of one country. As for forced migration, it means forcing residents to leave their homelands to other places they did not wish to leave, and the movement takes place within the country Or outside, this means that forced displacement, displacement and asylum are multiple images of one bleak face, the features of an increasingly aggravating tragedy and negatively reflecting on the social and political environment of the society in which it occurs.

\section{Internal displacement in Iraq}

\section{2-1 : The main causes of displacement after the fall of the regime:}

Iraq is characterized by the phenomenon of multiple nationalities, religions and sects, and relations between them have been marred by political, national and sectarian conflicts, which created multiple loyalties that began to distinguish between the people of the same country ${ }^{(10)}$

which has generated civil and sectarian wars, security coups ,economic and political turmoil , and looting and pillage. These

conditions force people to migrate from one place to another, so they move in large and small groups in search of security and stability ${ }^{(8)}$ 
, emerged as the political result of weak law factors and the weakness of the executive power and the lack of security which is one of the reasons that opened the country to many of the armed groups as well as acts of violence and armed raids and arrests random by the occupying forces, there are social factors, including the prevalence of the phenomenon of crime, threats and murder, also The economic factors are represented by many residents losing their livelihoods ${ }^{(11)}$.

The main reasons can be summarized as follows:

1- The occupation of Iraq by the US forces in 2003 and its practices against citizens, including arrest, torture and acts of violence.

2- The breakdown of the security situation in Iraq, the outbreak of sectarian violence and the emergence of militias and terrorist gangs

3- ISIS gangs expel and kill individuals who disagree with them in religion and principle.

4- The transformation of the original areas of the displaced into battlefields.

5- The economic uncertainty due to citizens losing their homes and depriving them of sources of livelihood.

\section{2-2 : The suffering of the displaced:}

Many of the displaced suffer Almchak lattes including:

1- Problems of Housing :The housing is an urgent necessity for every individual in the society being one of the motives of building the family and stability, most of the displaced people did not get housing simpler needed to live human health supplies are available where, as the families develop special arrangements for their housing, and it was clear from the survey for displaced people in 2014 , including from the housing complexes, including housing from public lands or in public

buildings, and some pa another housing buildings under Structure, including schools housing, others housing Shiite mosques ${ }^{(9)}$ 
2- Problems of the service : Displaced people need to various health and educational services, transportation and other, as the cause of displacement pressure on services so that you can not meet the requirements of

the population as well as the organs concerned the inability to provide services to the residents of old and new to the fact that the population movement was sudden and large numbers so that it there is pressure services in all sectors such as health, water, electricity and caused damage to the level of efficiency and performance of the group of beneficiaries, ${ }^{(11)}$ The educational institution is also facing a new and major challenge, which is the displaced students. There is a loss of educational opportunities. Also, many schools have been turned into housing for the displaced, and some schools have been affected by corruption deals, so they are destroyed and not outdated.

3- Problems of Economic : facing Displaceds problems of an economic majority of them became without work as the displacement of individuals or the hands of the worker in a particular area to another place to Ataatovr the same profession calls for unemployment, even in a while, but can not host areas to provide employment opportunities that they occupied in their cities before displacement and Asubho without The lowest financial return, as there is a need for work opportunities for the displaced and to meet their needs ${ }^{(8)}$

4- Problems of social and psychological : The disintegration of the Social gets within the community, which is exposed to the transformation processes or change has proceeded much of the armed groups to stir up sectarian strife among members of the society and thus led to the tearing up the fabric 's social and weak links and Keywords data social, displacement led to the spread of the phenomenon of crime and theft And moral corruption, beggary and school dropout is spreading in Iraqi society. ${ }^{(1)}$ The new life of the displaced generates many severe mental illnesses, as they struggle to obtain the daily sustenance needed for their survival, all of which has 
profound negative effects on the souls of the displaced in general, and women and children in particular.

5- Difficulty documenting and recording problems: The lack of documentation often leads to difficulties for Displaceds when they go to the authorities to register. A large number of individuals have been excluded from receiving aid from the government because the eligibility criteria are related to registration with the Ministry of Immigration and Displacement and are linked to the date of displacement, and some Displaceds hesitate to register the authorities out of fear for their personal safety, and could not Displaceds are not registered from renting or buying a property

or voting or registration of land or to register their children in school or receive medical treatment or access to services. ${ }^{(5)}$

\section{2 - 3 : The Legal Framework for the Protection of Internally Displaced Persons:}

The international community reached in 1951 to a special convention on the Status of Refugees, after the establishment of the High Commissioner for Refugees( UNHCR) has become the agreement more Hmolaovq Protocol in 1967 , as food - the geographical limitation and the time of the Convention, did not include this Agreement and the Protocol to Displaceds, in 1997 , issued the Guiding Principles on Internal Displacement but it did not reach the ranks of the agreement, but it 's their content and context do not come from a vacuum, but are not to SAS on international human rights law and international law, humanitarian and here are gaining strength, and met with respect and wide acceptance of the various countries, which gave such mandatory internationally. The ever-increasing proportions of internally displaced persons, the tragedy that this scene shows in the contemporary world, and the increasing awareness of the international community about the difficulties faced by the internally displaced have led to the issuance of guidelines on internal displacement. Then came the Kampala Agreement of the African Union for the Protection and Assistance 
of Internally Displaced Persons in 2009, which is the first legally binding agreement at the international and regional levels and specialized in the

affairs of internally displaced persons.It is considered the legal framework for the protection of Displaceds at the level of African countries.The strength of such a no agreement to enable them to secure legal protection mandatory for internally displaced persons, this protection is the responsibility of the state. Does not have a frame like this in the Middle East ,as it does not have only a few countries have national policies on internal displacement, although there is the recognition of the universal rights of internally displaced persons in accordance with the Guiding Principles on Internally Displaced Persons Act of 1998 required governments to protect their citizens are forgotten often They receive little help, as is currently happening with displaced families in Iraq and Syria.$^{(6)}$

\section{2 - 4 : governmental and non - governmental role:}

$2-4-1$ : government: the government 's role in the displaced file is very difficult and that it lacks the necessary capacity under international weak support, Maoda the Iraqi government before the exam is difficult, as the aid provided to displaced families from different parts of Iraq in 2014 is not satisfactory. ${ }^{(1)}$, politicians and stakeholders in the country are asking about how to resolve the crisis, the beginning did not specify who must carry Mswolah management of displaced persons crisis , and the formation of the Supreme Committee for the relief of the displaced by the Council of Ministers comprising representatives of the ministries (Defense ,Interior, Health ,Education, intelligence, finance, the Red Crescent ,the Cabinet Secretariat, the National Operations Center, Trade, Immigration, Displaced People, Housing and Recreation), and an amount of 3 billion has been allocated to contain the crisis. There was an absence of fruitful coordination between state institutions to contain the crisis of the displaced, the increase in the pace of military operations and political turmoil. There was also confusion, mismanagement and waste of funds allocated to the displaced and 
corruption, all of this did not give positive results in containing this crisis, which led to an increase in the suffering of the displaced, the number of internally displaced persons reached In 2014, nearly two million people were displaced, compared to the global average of 28.8 million displaced

people are distributed between Africa, Asia, the Middle East and other regions of the world, an average of 5, \%5of the total displaced people in the world, the rate is the highest by increasing the level of displaced figures also. There are legal impediments to the request of international aid ,including the fact that Iraq is not a signatory to the Agreement Refugees of 1951 and its 1967 Protocol .As Iraq was for a long host of refugees .In 2010 a new refugee law was reformulated and is still stuck in the corridors of the Iraqi parliament ${ }^{(4)}$

$2-4-2$ : authorities non - governmental: There are at the national level, other mechanisms of non-state and does not constitute one of its bodies, but working with them in parallel almost constitutes a presence profit last for the displaced not a provided protection for them, and between those authorities and local civil society and the media ${ }^{(15)}$

$2-4-3$ : civil society and the local: those non-State organizations, SPA independence about them, and the problem $v$ voluntarily by members

of society, in order to defend and disseminate its principles and objectives, its role has Duplicity (protection and assistance) to protect them from danger the mere presence of the displaced Inside camps that guarantee a kind of protection for the displaced who are targeted by violence during the course of hostilities, in addition to the reports issued by the members of these organizations represent a reference to know the violations and needs that accompany the duration of the presence of the displaced in the camps, including the International Red Cross and the Iraqi Red Crescent . ${ }^{(15)}$ 
$2-4-4$ : Media: reflect the ability of the Media in the protection of displaced people and help them along submit reports on their status as it is in fact, what profound effects happening on the actions of individuals and states, also the speed of doing so, it is pushing to be reminded that there is no place on the face of Earth is immune from access to him, so the parties seeking causing the creation of the refugee crisis and internally displaced persons to curb the work of the media through the use of electromagnetic weapons capable of jamming broadcasts authorities media hostile or

bombing stations television in them, Aa d flags and means of pressure even at the high level of Authorities by showing the horrors of war and its impact on civilians. The fact that the flags are late in reporting humanitarian crises affects the time for timely intervention on the part of countries, means that the absence of media coverage of the displaced pushes them into the trap of oblivion. ${ }^{(15)}$

Iraqi media are called calls tardiness for Relief for the displaced , as counting media representatives Iraqis to help the displaced in the conflict areas and national responsibility for Atnhsr only in the government 's efforts, but is a collective responsibility involving members of Iraqi society, all of the responsibility and location, said participants in this campaign say that the value Notional To participate in helping the displaced exceeds the material value provided by the donors by donating money, goods and housing to that, the Iraqi Media Network launched a campaign of "Displaced Persons is Our Responsibility" based on the principle that "the state's effort alone ,especially especially since the state is burdened with many burdens, must bear part of the original community." One of his responsibilities in this field, and the invitation considered that "families, merchants, businessmen, civil society organizations and employees can contribute, each according to his ability, to the national effort to relief the displaced ${ }^{(3)}$

$2-4-5$ : High Commission for Human Rights: was considered the High Commissioner for Human year 2014 the worst human situation at 
the level of only bad in Iraq because of the massive displacement wave that hit a number of Iraqi, after the control of the ISIS on cities, after they arrived in the numbers of displaced internally two million Two hundred and fifty thousand displaced persons, while the number of displaced persons outside Iraq has not been determined yet. ${ }^{(1)}$

$2-4-6$ : International organizations : In recent years, as the awareness of the international community to the plight of displaced inertly In 1992 , was appointed Secretary-General of the United Nations based on the request of the Commission on Human Rights representative on internally displaced internally to study the causes of internal displacement and the center of displaced IDP $\mathrm{n}$ internally in international law and the extent of interest in the status of The displaced and ways to improve protection for them. Whereas, the trend was towards the creation of appropriate normative and institutional frameworks for the protection of Displaceds, and then the development of guidelines in 1998. The United Nations drew the attention of the international community to the internal displacement crisis .Many governmental and nongovernmental organizations have expanded the boundaries of their mandate or the scope of their activities to more effectively address the needs of the internally displaced, and governments have become more responsive after realizing their primary responsibility to protect and assist the affected population under their authority ${ }^{(5)}$ to monitor a matrix trace of displacement, which is a tool for managing information of the International Organization for Migration displaced populations across Iraq and provide this tool information and data updated continuously for displaced people and their positions will take him into Aloattabaralawaiq security and access roads along the vast and complex nature of the flowing displacement., And through which the collection Specific information on the status and location of displaced persons on a regular basis , ${ }^{(17)}$ It appears from this that the role of international organizations is limited to providing advice and information and following up on developments in the issue of internal displacement and urging the Iraqi government to make efforts and funds to put an end to the suffering of the displaced .. 


\section{The third topic}

\section{Previous studies}

Previous studies related to the research topic were searched in periodicals and research abstracts, and related studies were found, the most important of which are:

1- The study of Hussein Karim Hamad Al-Saadi entitled "Spatial Analysis of Forced Migration to the City of Al-Kut" published in the College of Education, University of Wasit. The study area was represented in the city of Al-Kut, the center of Wasit Governorate. One of the reasons that led the researcher to study this phenomenon is not because it is a

phenomenon. population serious but also for being one of the geographical phenomena of the population that deserves study, it was adopted study the geographical method in the description and analysis and synthesis to reach the results explain the problem relying on the Department of immigration data and Displacement in Wasit, study some appeared conclusions that the most important migration occurs factors are mandatory involuntarily caused by factors Cairo, which the population cannot resist, has been characterized by sectarian and sectarian violence. The study made some recommendations, including improving the security situation

2- The study of Jabar Abd Jbeil and M.Qais Majeed Alloush entitled "Spatial variation of forced migration phenomenon in Iraq except for the Kurdistan region " This study was published in March 2014 at the University of Babylon / College of Education for Human Sciences .The place of study is represented in the governorates of Iraq except for the Kurdistan region. The research came to study internal forced migration between the provinces of the country and the research adopted the descriptive method. The study showed that forced migration is one of the serious social problems and its danger lies in its continuity, and the study also revealed the deterioration of the security aspect, which was 
represented by the weakness of the law from Among the most prominent factors of forced migration in Iraq

3- Study d .Ibrahim Daraji entitled "Refugee Problems and Ways to Treat them" This study was presented to the scientific forum organized by Naif University for Security Sciences / College of Strategic Sciences in Riyadh in 2011 under the title "Refugees in the Arab Region: Their Issues and their Treatment" This study deals with the reality of refugees in the world and seeks to raise a problem related to On the issue that a large number of the world's refugees are from and in the Arab region. The study presented the

4- extent of the problem in the Arab world,based on data from the United Nations High Commissioner for Refugees .This study highlighted the fact that Arab countries have weak accession to international conventions on refugees and the phenomenon of the absence of national legislation

and Arab regional treaties for refugees.Then the study concluded to end the causes of asylum, such as wars, conflicts, and sources of persecution and abuse. The study suggested that Arab countries work on two levels, Arab regional and national levels that ensure achieving the required balance between the rights of refugees on the one hand and the rights of host countries on the other hand.

5- Study Wrida Jandali entitled "The Role of the International Committee of the Red Cross in Protecting African Civilians : Forced Deportation during Armed Conflicts" This study was published in 2015 at the University of August 20, 1955 - Skikdah, Algeria. The aim of the study is to shed light on the causes of the crime of forcible transfer of African civilians and the consequences thereof. The study emerged with the conclusion that the International Committee of the Red Cross provides effective protection and assistance to both refugees and forcibly displaced persons in Africa..

Previous studies on topics of migration and internal displacement gathered as a phenomenon that occurs for reasons 
compelling mandatory shrug of the population to resist, either studies on Iraqi displacement gathered as the phenomenon came to a number of reasons, political factors, social and ethnic led to the security situation coup and the proliferation of militias and the lack of state control over the situation, which led to a large and varied suffering for the displaced.

\section{Chapter Three}

\section{Analyze and interpret data}

The first requirement: a presentation and interpretation of the results of the national survey of displaced Iraqis for the year 2014

Table No. (1) shows the numbers of Displaced from the Iraqi governorates towards the central and northern governorates and Southern for 2014

\begin{tabular}{|c|c||c||}
\hline Governorate & the number & $\%$ \\
\hline \hline Kirkuk & 53972 & 35.97 \\
\hline \hline Baghdad & 29273 & 19.52 \\
\hline \hline Diyala & 25497 & 16.99 \\
\hline \hline Karbala & 11034 & 7.35 \\
\hline \hline Najaf & 10438 & 6.96 \\
\hline \hline Babylon & 8545 & 5.70 \\
\hline \hline Wasit & 3411 & 2.27 \\
\hline \hline Qadisiyah & 2726 & 1.82 \\
\hline \hline Basra & 1603 & 1.07 \\
\hline \hline Dhi Qar & 1445 & 0.96 \\
\hline \hline Maysan & 1072 & 0.72 \\
\hline \hline Muthanna & 1011 & 0.67 \\
\hline \hline Total & 150027 & 100 \\
\hline
\end{tabular}




\section{Source :Republic of Iraq, Ministry of Planning,}

\section{Central Bureau of Statistics}

Can be seen from the table (1) The number of internally displaced families to the provinces surveyed, the number of households only esthetic (150027) IDP family, estimate the average size of displaced families (6.8)Per person per family, as the number of family members(782392)Individual, the highest percentage was concentrated in Kirkuk governorate, when it reached(35.97\%) Of the displaced families, followed by the governorate of Baghdad (19.52\%) A displaced family, then Diyala (16.99\%)Displaced families, the reason for the exodus of descent belongs to the large of the number of families to the central regions of the northern and central compared to the proportions in the southern regions is its proximity to the spatial and sectarian hot spots, as well as the stability of the security relative in the host areas, and the presence of relatives and friends in those provinces, making it a positive pole for The displaced.

Table (2) shows the relative distribution of individuals by age 6Years or more ,internally displaced Iraqi families are not currently enrolled in education due to displacement and according to its causes in 2014.

\begin{tabular}{|l||c|}
\hline \multicolumn{1}{|c||}{ Reason } & $\%$ \\
\hline \hline Financial reasons & $35 \%$ \\
\hline \hline There are no schools nearby & $34 \%$ \\
\hline \hline Not wanting to continue education & $13 \%$ \\
\hline \hline Other & $11 \%$ \\
\hline \hline Failure to urinate them in school & $7 \%$ \\
\hline \hline Total & $100 \%$ \\
\hline
\end{tabular}


Source: Republic of Iraq, Ministry of Planning, Central Bureau of Statistics

It is noted from Table (2) that the highest percentages among the reasons for leaving education are for individuals of age 6 For years or more, it is the material cause when it is reached(35\%) Of the displaced who drop out of schools, followed by the lack of schools near the camp for the displaced, as the percentage reached(34\%) School dropouts and displaced persons (13\%) The percentage of students who do not have a desire to continue education $(\%$ 11)They drop out of schools for various reasons, which may be psychological, social or security reasons, as for students who have not been accepted into schools( $\%$ 7)Maybe not bring official documents during their displacement or because of the increasing number of students, as was t set records for schools can not be absorbed.

Table (3) shows the number of internally displaced Iraqi families who received assistance provided by the Ministry of Displacement and Migration and according to the type of assistance for the year 2014.

\begin{tabular}{|c||c|c|}
\hline Kind of assistance & the number & $\%$ \\
\hline \hline Cash & 37440 & 24.95 \\
\hline \hline Kitchen set & 12469 & 8.31 \\
\hline \hline food basket & 9993 & 6.66 \\
\hline \hline clothes and shoes & 2659 & 1.77 \\
\hline Other & 1809 & 1.20 \\
\hline Home furnishings & 1514 & 1.01 \\
\hline
\end{tabular}

Source: Republic of Iraq, Ministry of Planning, Central Bureau of Statistics

It is evident from Table (3) that the aid of all kinds provided to displaced Iraqis by the Ministry of Immigration and Displacement is much less than the number of internally displaced families, which is very large.(150027) A displaced family, the percentage of cash assistance 
reached) 24.95 (\%Of the total number of displaced persons $(8.31 \%)$ From the displaced families they received a kitchen set and(6.66\%) From the number of displaced families they received a food basket (1.77\%) Of the number of displaced families, they received clothes and shoes as aid, while the other aid was its percentage $(\%$ 1.20)Of the number of displaced families, the percentage of assistance was for household furnishings(\% 1.01) From the number of displaced families, this means that the amount of aid provided by the Ministry of Immigration and Displacement does not rise to the size of the problem.

Table No. (4) shows the number of assistance provided to displaced families according to the bodies providing assistance for the year 2014

\begin{tabular}{|c|c|}
\hline The entity & the number \\
\hline \hline Religious bodies & 19530 \\
\hline \hline $\begin{array}{c}\text { international organizations } \\
\text { leaders( }\end{array}$ & 17759 \\
\hline \hline $\begin{array}{c}\text { Civil society organizations ) notables ,tribal } \\
\text { Other government agencies }\end{array}$ & 16629 \\
\hline \hline Local government / provincial councils & 9894 \\
\hline
\end{tabular}

\section{Source: Republic of Iraq, Ministry of Planning, Central Bureau of Statistics}

J noted in the table (4) the weakness of the government 's role in providing aid as accounted for the assistance provided by local governments and provincial councils lower ratios(7.2\%) The aid amounted to other government agencies (14.3\%)While the highest percentages of aid were provided by religious authorities, when it reached) $(28.3 \% \mathrm{Of}$ the total amount of 
aid ,followed by the aid provided by international organizations, which is very large (25.8\%) From the total amount of aid, then the aid of civil society, where it reached $(24.4 \%)$.

Table (5) shows the relative distribution of displaced families that were subjected to torture of both sexes in 2014

\begin{tabular}{|c||c||c||c|}
\hline $\begin{array}{c}\text { Age } \\
\text { Sex }\end{array}$ & $\begin{array}{c}\text { under } 18 \text { years old } \\
\%\end{array}$ & $\begin{array}{c}18 \text { And more } \\
\%\end{array}$ & Total \\
\hline \hline Male & 8.18 & 7.34 & 5.53 \\
\hline female & 6.20 & 9.25 & 5.46 \\
\cline { 1 - 2 } Total & 4.39 & 6.60 & 100 \\
\hline
\end{tabular}

Source: Republic of Iraq, Ministry of Planning, Central Bureau of Statistics

Table (5) reflects the brutal gangs the criminal, which led to the displacement $(18.8 \%)$ Male and $(20.6 \%)$ Of the females age groups less than 18 Year and (34.7\%) Male and (25.5\%)Of female adults due to being tortured by these terrorist gangs.

Table (6) shows the relative distribution of displaced families according to the type of housing and the governorate that is the most frequent for the year 2014

\begin{tabular}{|l|l|l|}
\hline Accommodation type & $\%$ & Provinces \\
\hline $\begin{array}{l}\text { Housing for rent or with } \\
\text { host families }\end{array}$ & 82.5 & $\begin{array}{l}\text { All governorates except Naynawa, } \\
\text { Anbar and Salah al-Din }\end{array}$ \\
\hline Houses of worship & 2.10 & Najaf, Karbala, Babylon, Wasit \\
\hline The camps & 0.3 & Maysan, Diyala, Kirkuk \\
\hline Hotels & 4.2 & Karbala, his sight \\
\hline School buildings & 0.1 & Muthanna, Baghdad \\
\hline
\end{tabular}


ISSN (print): 2706- 6908, ISSN (online): 2706-6894

Vol.15 No.2 June 2020

\begin{tabular}{|l|l|l|}
\hline Caravan & 9.0 & Dhi Qar, Diyala \\
\hline Total & 100 & \\
\hline
\end{tabular}

Source: Republic of Iraq, Ministry of Planning, Central Bureau of Statistics

Shows a table (6) that(17.5\%) Only of the displaced families live in critical places, while the largest percentage is very large $(82.5 \%)$ Of the number of families residing in rental housing or with host families .Reached the proportion of residents in places of worship , the highest ratios of critical places, as it was(10.2\%)In the governorates of Najaf, Karbala, Babil and Wasit, the high percentage in these governorates may be due to their proximity to the original areas of the displaced. As for Maysan, Diyala and Kirkuk, the percentage of displaced persons in the camps reached(\% 3) Of the Displaceds residing in critical places, the percentage of those residing in hotels is (2.4\%) It is distributed between the governorates of Karbala and Basra. As for the Displaceds residing in schools, their percentage reached $(\%$ 1) It is distributed between the governorates of Maysan and Baghdad, in the governorates of Dhi Qar and Diyala. The percentage of displaced people who live in the caravan $(0.9 \%)$ Of the residents in critical places of the displaced.

The second requirement: a presentation and interpretation of the information matrix that tracks the displaced Iraqis for the period from January 2014 to April 2015

Table(7) shows the number of individuals and families displaced during the year 2014 Distributed according to the dates of the three distinct waves 
University of Thi-Qar Journal

ISSN (print): 2706- 6908, ISSN (online): 2706-6894

Vol.15 No.2 June 2020

\begin{tabular}{|c|c|c|c|}
\hline Internally displaced individuals & $\begin{array}{c}\text { Internally displaced } \\
\text { families }\end{array}$ & $\%$ & $\begin{array}{c}\text { Observation } \\
\text { period }\end{array}$ \\
\hline \hline 564.888 & 9448 & 21 & Before June 2014 \\
\hline 661.500 & 110.250 & 25 & June-July2014 \\
\hline 886.032 & 147.672 & 33 & Father 2014 \\
\hline \hline 561,660 & 93.610 & 21 & Post 1 September \\
\hline \hline $2,674,080$ & 445.680 & 100 & Total \\
\hline
\end{tabular}

Source : Table D well prepared by the researcher relying on the International Organization for Migration data

Table (7) shows that there are three main and specific waves of displacement in Iraq since January 2014. These three waves of displacement address the main conflicts, and each wave is traditionally classified according to its period, from January to May, then June and July, then August 2014, then

from August to September, then to post - September, the third wave .otsnf more according to the periods of August 2014 and the postSeptember 1

Table ( 8 ) shows the Iraqi displacement during the year2014 Distributed according to the dates of the three distinct waves

\begin{tabular}{|c|c|c|}
\hline Displacement wave & Periods & $\begin{array}{c}\text { The number of } \\
\text { displaced people }\end{array}$ \\
\hline \hline \multirow{5}{*}{ First } & $2014 / 3 / 2$ & \\
& $2014 / 3 / 27$ & 397.104 \\
& $2014 / 4 / 5$ & \\
& $2014 / 4 / 12$ & 444.050 \\
\cline { 2 - 3 } & $2014 / 4 / 20$ & \\
& $2014 / 4 / 27$ & \\
& $2014 / 5 / 4$ & \\
\hline
\end{tabular}


University of Thi-Qar Journal

ISSN (print): 2706- 6908, ISSN (online): 2706-6894

Vol.15 No.2 June 2020

\begin{tabular}{|c|c|c|}
\hline & $\begin{array}{c}2014 / 5 / 27 \\
2014 / 6 / 3 \\
2014 / 6 / 10\end{array}$ & 478,660 \\
\hline The second wave & $\begin{array}{c}2014 / 6 / 19 \\
2014 / 6 / 25 \\
2014 / 7 / 2 \\
2014 / 7 / 9 \\
\end{array}$ & 886.056 \\
\hline \multirow{2}{*}{$\begin{array}{c}\text { The first wave of the } \\
\text { wave } \\
\text { The third }\end{array}$} & $\begin{array}{c}2014 / 7 / 16 \\
2014 / 8 / 7 \\
2014 / 8 / 18 \\
2014 / 8 / 24 \\
\end{array}$ & 1.709 .178 \\
\hline & $\begin{array}{c}2014 / 9 / 1 \\
2014 / 9 / 8 \\
2014 / 9 / 14 \\
2014 / 9 / 28 \\
\end{array}$ & 1.814 .862 \\
\hline \multirow{4}{*}{$\begin{array}{c}\text { The second wave of } \\
\text { the wave } \\
\text { The third }\end{array}$} & $\begin{array}{c}2014 / 10 / 12 \\
2014 / 10 / 26 \\
2014 / 11 / 9 \\
\end{array}$ & 1.898 .844 \\
\hline & $\begin{array}{l}2014 / 11 / 27 \\
2014 / 12 / 24 \\
\end{array}$ & 2.123 .340 \\
\hline & $\begin{array}{l}2015 / 1 / 15 \\
2015 / 1 / 29 \\
\end{array}$ & 2.472 .444 \\
\hline & $\begin{array}{c}2015 / 2 / 12 \\
2015 / 2 / 26 \\
2015 / 3 / 12 \\
2015 / 3 / 26 \\
2015 / 4 / 9\end{array}$ & $2,683,668$ \\
\hline
\end{tabular}

Reference :: The table was prepared by the researcher based on international organization for migration data for the period 2014-2015

Table (8) shows that the second wave of displacement, which came because of the fall of Mosul Governorate at the hands of terrorist ISIS gangs, starting from June 10 until the end of August, is the 
most violent wave of displacement in the region, reaching the highest rates in June-July (\% 26) Until August (33\%)Of the numbers of internally displaced people, where a large and continuous influx of displaced people is observed.In general, there is an increase in the size of the displaced population continuously in the three waves of displacement, as the number of internally displaced Iraqis reached until September(2674080) A displaced family (so that the general average size of a displaced family is 6 members )

Table (9): the qualitative composition of the displaced population, broken down by age groups for the year 2014

\begin{tabular}{|l|l|l|l|}
\hline Sex Categories & Males \% & Female \% & Total \\
\hline $0-5$ & 6.9 & 7.1 & 14 \\
\hline $6-14$ & 10.7 & 11.3 & 22 \\
\hline $15-24$ & 10.4 & 11.1 & 21.5 \\
\hline $25-59$ & 16.6 & 17.6 & 34.2 \\
\hline 60 And more & 4.0 & 4.2 & 8.2 \\
\hline Total & 48.6 & 51.4 & 100 \\
\hline
\end{tabular}

\section{Reference :: The table was prepared by the researcher based on INTERNATIONAL ORGANIZATION FOR MIGRATION data for the period 2014-2015}

It is noticed in general from Table (9) that the number of males is close to the number of females , as it formed the proportion of males(48.6\%) And percentage of females (51.4\%)It is also evident that there is a high percentage of displaced persons for both genders for the age group (59-25) This category has a significant impact on the side of the economic being category produced, the displacement of groups working in a particular area to another place has to Ataatovr the same occupations lead to unemployment even until especially farm owners or professionals, notes from the table too close to the proportion of males with females For all age 
groups, this is due to the fact that migration is a mass migration and does not belong to a specific age group.

Table (10) accommodation arrangements for all internally displaced persons in2014

\begin{tabular}{|l|l|}
\hline Shelter arrangements & $\%$ \\
\hline $\begin{array}{l}\text { Buildings under } \\
\text { construction }\end{array}$ & 14 \\
\hline Religious buildings & 6 \\
\hline Illegal settlements & 3 \\
\hline School buildings & 1 \\
\hline Unknown & 1 \\
\hline Rented houses & 38 \\
\hline Host families & 26 \\
\hline Hotels or hostels & 2 \\
\hline The camps & 9 \\
\hline Total & 100 \\
\hline
\end{tabular}

Reference :: The table was prepared by the researcher based on international organization for migration data for the period 2014-2015

Table (10) shows that the special arrangements for housing Displaceds for the year 2014 It is the most common as it formed the largest and largest proportion $(\%$ 66) Of the number of internally displaced persons, i.e .nearly one million displaced Iraqis, where they were $(38 \%)$ They live in rented houses, $(\%$ 26) They live with host families and $(\%$ 2) They live in hotels and hostels. As for the rest of the displaced, they live in inadequate shelters, which include buildings under construction, at a rate $(\%$ 4) Religious buildings by (\% 6) Illegal 
ISSN (print): 2706- 6908, ISSN (online): 2706-6894

\section{Vol.15 No.2 June 2020}

settlements by(\% 3), Schools by(\% 1) The percentage of Displaceds residing in unknown places, that is, inaccessible places where the type of shelter cannot be determined .(\% 1) The percentage of housing in the camps that the government considers official camps is (9\%) It is the lowest of the three housing arrangements, which reflects the weakness of the government in arranging places of residence for the displaced.

Table (11) shows the number of displaced Iraqi families during the year2014 According to the period of displacement and the governorate of the original home

\begin{tabular}{|c|c|c|c|c|c|c||}
\hline $\begin{array}{c}\text { Period } \\
\text { The original } \\
\text { province }\end{array}$ & $\begin{array}{c}\text { Before } \\
\text { June }\end{array}$ & $\begin{array}{c}\text { June- } \\
\text { July }\end{array}$ & Father & After September 2014 & Total & $\%$ \\
\hline \hline Anbar & 546402 & 57270 & 16464 & 190746 & 810882 & 30 \\
\hline \hline Babylon & 1290 & 10320 & 10404 & 10692 & 32706 & 1 \\
\hline \hline Baghdad & 4050 & 18468 & 18312 & 23382 & 64212 & 2 \\
\hline Basra & 60 & & & & 60 & 0 \\
\hline \hline Diyala & 7182 & 116052 & 40086 & 78522 & 241842 & 9 \\
\hline Erbil & & & 27786 & 14274 & 42060 & 2 \\
\hline Kirkuk & 198 & 10032 & 9984 & 41880 & 62094 & 2 \\
\hline Naynawa & 1356 & 261204 & 686088 & 75738 & 1024386 & 38 \\
\hline \hline Salahuddin & 4350 & 188148 & 76908 & 126426 & 395832 & 15 \\
\hline \hline Dhi Qar & & 6 & & & 6 & 0 \\
\hline \hline Total & 564888 & 661500 & 886032 & 561660 & 2674080 & 100 \\
\hline \hline$\%$ & 21 & 25 & 33 & 21 & 100 & \\
\hline \hline
\end{tabular}

Reference :: The table was prepared by the researcher based on INTERNATIONAL ORGANIZATION FOR MIGRATION data for the period 2014-2015 
It can be seen from Table (11). In general, the governorates( Naynawa , Anbar, and Salah al-Din) recorded the highest rates of displaced families, including $(38 \%, 30 \%$ And $15 \%)$ In a row, in the period before June, which represented the first wave of Iraqi displacement in a year 2014The province Alonbarsgelt the highest number of displaced

families , as was(546402)Any equivalent (96.7\%)Of the number of families displaced due to the terrorist operations that affected the western region of Iraq.

The second wave of displacement (June-July) is the period that followed the fall of the province of Naynawa by troops Daesh recorded the province of Naynawa , the highest number since reached(261204) Any equivalent (39.5\%) Of the displaced families for the months of June and July, followed by Salah al-Din Governorate, where the number of displaced families reached (188148) Any rate $(28.44 \%)$ Of the total number of displaced families, then Diyala Governorate, the number of displaced families during this wave has reached(116052) Any rate (17.5\%) The remaining number is distributed from the total number of displaced persons of this wave, and the adult(661500) Among the other governorates mentioned in the table.

The third wave is divided into two periods, the first in the month of August and the second until after September. We note from the table that Naynawa governorate recorded(686088) Of the number of displaced families, i.e. a percentage $(77.4 \%)$ Of the total displaced persons during the month of August, the period after September, the largest percentage was in Anbar Governorate, as the number of displaced families reached(190746)Any equivalent (33.96\%) Of the number of displaced families during this period, followed by Salah al-Din Governorate, the number of displaced families was among them (126426)Any rate $(22.51 \%)$ Of the number of displaced families. 


\section{The third requirement: Presentation and interpretation of the results of the study}

The weighted average and percentage weight of the questionnaire items were calculated by taking the views of the research sample, who are (78) individuals, distributed in Table ( 12 ) according to their workplace and table (13) according to their academic qualification

place of work

Table (12) Distribution of the sample according to the

\begin{tabular}{|c|c|}
\hline Workplace & the number \\
\hline \hline Ministry of Immigration and Displacement & 15 \\
\hline \hline Religious organizations and entities & 28 \\
\hline \hline Journalists ,jurists and university professors & 35 \\
\hline \hline Total & 78 \\
\hline
\end{tabular}

\section{Reference :: the table prepared by the researcher}

Table No. (13) Academic achievement for the sample population for the year 2014

\begin{tabular}{|c||c|}
\hline Academic achievement & the number \\
\hline PhD & 15 \\
\hline M.A. & 22 \\
\hline Bachelor & 25 \\
\hline \hline Technical Diploma & 16 \\
\hline \hline Total & 78 \\
\hline
\end{tabular}

\section{Reference :: the table prepared by the researcher}

It is evident from Tables No. (12) and Table No. (13) the distribution of the sample members according to their place of work and their scientific qualification. This increases the confidence in the results of the study because their work is in contact with this phenomenon and because most of the respondents are able to answer the questions and ideas presented in this study. 
University of Thi-Qar Journal

ISSN (print): 2706- 6908, ISSN (online): 2706-6894

The results of the study show the extent of convergence in the views of the sample members represented by the percentile and weighted mean values and at the level of the four axes of the questionnaire.

Table (14) shows the responses of the sample members, the weighted mean, and the percentile weight for the axis of displacement for the year 2014

\begin{tabular}{|c|c|c|c|c|c|c|c|c|}
\hline $\mathrm{T}$ & $\begin{array}{c}\text { Paragraph } \\
\text { arrangement }\end{array}$ & $\begin{array}{c}\mathrm{I} \\
\text { totally } \\
\text { agree }\end{array}$ & $\begin{array}{c}\mathrm{I} \\
\text { agree }\end{array}$ & $\begin{array}{c}\text { To } \\
\text { some } \\
\text { extent }\end{array}$ & $\begin{array}{c}\text { Strongly } \\
\text { disagree }\end{array}$ & $\begin{array}{c}\text { I do } \\
\text { not } \\
\text { agree }\end{array}$ & $\begin{array}{c}\text { Weighted } \\
\text { average }\end{array}$ & $\begin{array}{c}\text { Weight } \\
\text { percent }\end{array}$ \\
\hline $\begin{array}{c}\text { The security } \\
\text { situation is one of } \\
\text { the reasons that led } \\
\text { to the displacement }\end{array}$ & 59 & 15 & 0 & 0 & 4 & 4.60 & 92 \\
\hline $\begin{array}{c}\text { The phenomenon of } \\
\text { displacement was } \\
\text { due to political } \\
\text { reasons }\end{array}$ & 49 & 7 & 14 & 4 & 4 & 4.19 & 83.8 \\
\hline $\begin{array}{c}\text { Religious and } \\
\text { ethnic beliefs } \\
\text { are one of the } \\
\text { reasons for the } \\
\text { displacement }\end{array}$ & 32 & 15 & 17 & 4 & 10 & 3.71 & 74.2 \\
\hline $\begin{array}{c}\text { The economic side } \\
\text { contributed as part } \\
\text { of the drivers of } \\
\text { displacement }\end{array}$ & 7 & 28 & 8 & 11 & 24 & 2.78 & 55.6 \\
\hline & $\begin{array}{c}\text { The overall average } \\
\text { The }\end{array}$ & 36.75 & 16.25 & 9.75 & 4.75 & 10.5 & 3.82 & 76.4 \\
\hline
\end{tabular}

Reference :: the table prepared by the researcher 
It is noticed from Table (14) that the weighted mean (4.60) And weight percentile(92)Occupied the first place, which is higher than the general average, in the focus of research into the causes of displacement, that is, the first and main reason for displacement is due to security reasons, political reasons come after security, as this paragraph has been achieved in the middle likely (4.19)and weight percent(83.8), While the other causes a weighted average weight percentage achieved less than the average at the center of the reasons, where he occupied the religious side ranked third in the causes of displacement, where the weighted average (3.71) and weight percent(74.2) The reason is due to the outbreak of sectarian

violence .As for the economic reason, it was last ranked because it had an arithmetic average (2.72)and weight percent(55.6) The researcher believes that this cause is an indirect cause in an axis The causes came as a result of the existence of the three previous reasons.

Table (15) shows the responses of the sample members, the weighted mean and the percentage weight for the axis of the concerned authorities for the year 2014

\begin{tabular}{|c||c||c||c||c||c||c|c||c||}
\hline $\mathrm{T}$ & $\begin{array}{c}\text { Paragraph } \\
\text { arrangement }\end{array}$ & $\begin{array}{c}\mathrm{I} \\
\text { totally } \\
\text { agree }\end{array}$ & $\begin{array}{c}\mathrm{I} \\
\text { agree }\end{array}$ & $\begin{array}{c}\text { To } \\
\text { some } \\
\text { extent }\end{array}$ & $\begin{array}{c}\text { Strongly } \\
\text { disagree }\end{array}$ & $\begin{array}{c}\text { I do } \\
\text { not } \\
\text { agree }\end{array}$ & $\begin{array}{c}\text { Weighted } \\
\text { average }\end{array}$ & $\begin{array}{c}\text { Weight } \\
\text { percent }\end{array}$ \\
\hline & $\begin{array}{c}\text { The presence } \\
\text { of corruption } \\
\text { in the } \\
\text { management } \\
\text { of the } \\
\text { displaced } \\
\text { persons file } \\
\text { has led to the } \\
\text { failure to } \\
\text { control the }\end{array}$ & 42 & 21 & 11 & 4 & 0 & 4.29 & 85.8 \\
\hline
\end{tabular}


ISSN (print): 2706- 6908, ISSN (online): 2706-6894

\begin{tabular}{|c|c|c|c|c|c|c|c|c|}
\hline & crisis & & & & & & & \\
\hline 2 & $\begin{array}{l}\text { The lack of } \\
\text { seriousness } \\
\text { of } \\
\text { international } \\
\text { organizations } \\
\text { in dealing } \\
\text { with the } \\
\text { internally } \\
\text { displaced in } \\
\text { Iraq } \\
\end{array}$ & 25 & 28 & 18 & 3 & 4 & 3.86 & 77.2 \\
\hline 3 & $\begin{array}{l}\text { Religious } \\
\text { actors have a } \\
\text { major role in } \\
\text { helping the } \\
\text { internally } \\
\text { displaced }\end{array}$ & 18 & 28 & 17 & 6 & 9 & 3.51 & 70.2 \\
\hline 4 & $\begin{array}{l}\text { Civil society } \\
\text { organizations } \\
\text { in Iraq have } \\
\text { a role in } \\
\text { helping the } \\
\text { displaced } \\
\end{array}$ & 14 & 28 & 22 & 7 & 7 & 3.45 & 69 \\
\hline 5 & $\begin{array}{c}\text { Iraqi flags } \\
\text { launch large } \\
\text { calls } \\
\text { for relief of } \\
\text { the displaced }\end{array}$ & 7 & 35 & 14 & 8 & 14 & 3.17 & 63.4 \\
\hline 6 & There is a & 4 & 14 & 24 & 14 & 22 & 2.54 & 50.8 \\
\hline
\end{tabular}




\begin{tabular}{||c||c||c|c|c|c|c||c||}
\hline $\begin{array}{c}\text { containment } \\
\text { of the } \\
\text { displaced } \\
\text { persons } \\
\text { crisis by the } \\
\text { relevant } \\
\text { authorities }\end{array}$ & & & & & & & \\
\hline \hline $\begin{array}{c}\text { The overall } \\
\text { average }\end{array}$ & 18.33 & 25.66 & 17.66 & 7 & 9.33 & 3.47 & 69.4 \\
\hline
\end{tabular}

\section{Reference :: the table prepared by the researcher}

It is noted from Table (15) that the paragraphs that ranked first, second and third achieved a weighted average and a percentage weight less than the general weighted average and its percentage weight, that the paragraph regarding the existence of corruption in the management of the IDP file ranked first in the axis of the role of the relevant authorities in resolving the crisis Internally displaced persons in Iraq, where the weighted average is (4.29)and weight percent(85.8)This reflects the viewpoints of the sample members of the existence of corruption in the management of the IDP file, which led to the contribution in not containing the crisis by the relevant authorities, while the paragraph on the lack of seriousness of international organizations in dealing with the IDP file in Iraq ranked second with a weighted average(3.86)and in percent weight(77.2)The reason for this is due to the lack of a legal framework that binds these organizations to a real and effective role. Also, non-governmental bodies contributed to an acceptable level in containing the crisis compared to the role of the relevant authorities, where the religious authorities ranked third with a weighted average(3.51)And weight percent(70.2)And civil society organizations ranked fourth with the weighted average(3.45)And weight percent(69), The media has a role in contributing to contain the crisis by submitting reports on their situation as it is in reality to individuals and countries. This paragraph has achieved a weighted average(.3.17)And weight percent(63.4), The paragraph ranked last and achieved the lowest weighted 
ISSN (print): 2706- 6908, ISSN (online): 2706-6894

average of (2.54)And weight percent(50.8)It is the existence of containment by the relevant authorities. The researcher believes that the previous paragraphs in this axis are the reason for not containing the crisis.

Table (16) shows the responses of the sample individuals, the weighted mean and the percentile weight for the displacement effects axis for the year 2014

\begin{tabular}{|c|c|c|c|c|c|c|c|}
\hline Paragraph arrangement & $\begin{array}{c}\text { I } \\
\text { totally } \\
\text { agree }\end{array}$ & $\begin{array}{c}\text { I } \\
\text { agree }\end{array}$ & $\begin{array}{c}\text { To } \\
\text { some } \\
\text { extent }\end{array}$ & $\begin{array}{c}\text { Strongly } \\
\text { disagree }\end{array}$ & $\begin{array}{c}\text { I do } \\
\text { not } \\
\text { agree }\end{array}$ & $\begin{array}{c}\text { Weighted } \\
\text { average }\end{array}$ & $\begin{array}{c}\text { Weight } \\
\text { percent }\end{array}$ \\
\hline $\begin{array}{c}\text { There is a deterioration in } \\
\text { the health and } \\
\text { psychological status of the } \\
\text { displaced }\end{array}$ & 67 & 11 & 0 & 0 & 0 & 4.86 & 97.2 \\
\hline $\begin{array}{c}\text { Housing arrangements for } \\
\text { the displaced do not meet } \\
\text { the requirements of } \\
\text { protection or health } \\
\text { services }\end{array}$ & 56 & 22 & 0 & 0 & 0 & 4.72 & 94.4 \\
\hline $\begin{array}{c}\text { The phenomenon of } \\
\text { displacement caused a loss } \\
\text { of educational }\end{array}$ & 46 & 21 & 7 & 0 & 4 & 4.35 & 87 \\
$\begin{array}{c}\text { opportunities for most of } \\
\text { the students }\end{array}$ & 29 & 42 & 4 & 0 & 3 & 4.21 & 84.2 \\
\hline $\begin{array}{c}\text { Displacement creates } \\
\text { crises and other social } \\
\text { problems such as theft, } \\
\text { crime, begging and others }\end{array}$ & 29 & & & & & \\
\hline \hline
\end{tabular}




\section{University of Thi-Qar Journal}

ISSN (print): 2706- 6908, ISSN (online): 2706-6894

Vol.15 No.2 June 2020

\begin{tabular}{|c|c|c|c|c|c||c|c|}
\hline $\begin{array}{c}\text { Internal displacement has } \\
\text { contributed to the spread of } \\
\text { unemployment in the host } \\
\text { areas }\end{array}$ & 32 & 33 & 9 & 4 & 0 & 4.19 & 83.8 \\
\hline The overall average & 46 & 25.8 & 4 & 0.8 & 1.4 & 4.46 & 89.2 \\
\hline
\end{tabular}

\section{Reference :: the table prepared by the researcher}

It is evident from Table (16) that the paragraphs ranked first, second and third achieved a weighted average and a percentage weight higher than the general average. Whereas, the deterioration of the health and psychological status of internally displaced persons obtained the highest estimates as it reached the weighted average. (4.86)and weight percentile(97.9)The reason for this is due to the participation of the displaced in housing, food

and clothing as well. This was clear through the paragraph that ranked second in the paragraphs of this axis, where it was found that the housing arrangements do not meet the requirements of protection or health services through the average that reached(4.72)And weight percentile(94.4)It is evident that there is a loss of educational opportunities for most of the students due to the displacement crisis, as this paragraph ranked third in the

effects of internal displacement, as it achieved a weighted average(4.35)And weight percent(87)The reason is due to the demolition of some schools or converting them into housing for the displaced. Also, the number of students reached record numbers per class, or the reason is due to some displaced persons losing their identity papers, and the paragraph that ranked fourth in this axis is that displacement has caused social problems such as theft, crime and begging. Where the average of this paragraph (4.21)And weight percentile(84.2)The reason is due to the lack of privacy in the housing of the displaced, which led to the spread of negative habits among the displaced individuals.(4.19)And weight percent(83.8)This means that internal 
ISSN (print): 2706- 6908, ISSN (online): 2706-6894

displacement has a great impact on the emergence of the phenomenon of unemployment in the areas hosting the displaced, and the reason is that these areas are unable to provide suitable job opportunities for the displaced.

Table (17) shows the responses of the sample individuals, the weighted mean , and the percentage weight of the solutions axis for the year 2014

\begin{tabular}{|c|c|c|c|c|c|c|c|}
\hline Paragraph arrangement & $\begin{array}{c}\text { I } \\
\text { totally } \\
\text { agree }\end{array}$ & $\begin{array}{c}\text { I } \\
\text { agree }\end{array}$ & $\begin{array}{c}\text { To } \\
\text { some } \\
\text { extent } \\
\end{array}$ & $\begin{array}{l}\text { Strongly } \\
\text { disagree }\end{array}$ & $\begin{array}{c}\text { I do } \\
\text { not } \\
\text { agree }\end{array}$ & $\begin{array}{l}\text { Weighted } \\
\text { average }\end{array}$ & $\begin{array}{l}\text { Weight } \\
\text { percent }\end{array}$ \\
\hline $\begin{array}{l}\text { The final solution to this } \\
\text { crisis is to clear the areas } \\
\text { of displacement by } \\
\text { raising the state's military } \\
\text { capabilities and building } \\
\text { conditions that encourage } \\
\text { return to the liberated } \\
\text { areas }\end{array}$ & 52 & 14 & 12 & 0 & 0 & 4.51 & 90.2 \\
\hline $\begin{array}{l}\text { Building housing units } \\
\text { away from the military } \\
\text { conflict greatly } \\
\text { contributes to alleviating } \\
\text { the crisis }\end{array}$ & 47 & 26 & 0 & 0 & 5 & 4.41 & 88.2 \\
\hline $\begin{array}{c}\text { In your } \\
\text { opinion ,identifying } \\
\text { a permanent, independent } \\
\text { body responsible for } \\
\text { disasters and crises in the } \\
\text { country, the displacement } \\
\text { would have been better } \\
\text { contained } \\
\end{array}$ & 35 & 32 & 7 & 3 & 1 & 4.24 & 84.8 \\
\hline
\end{tabular}




\begin{tabular}{|c|c|c|c|c|c|c|c|}
\hline $\begin{array}{l}\text { Urging for peaceful } \\
\text { coexistence in light of } \\
\text { reconciliation and } \\
\text { acceptance among Iraqi } \\
\text { groups contributes to } \\
\text { solving the crisis }\end{array}$ & 33 & 31 & 4 & 3 & 7 & 4.03 & 80.6 \\
\hline $\begin{array}{l}\text { He requested } \\
\text { international and } \\
\text { regional support } \\
\text { to contain this crisis and } \\
\text { urged the international } \\
\text { community to provide } \\
\text { support to the displaced } \\
\text { by strengthening their } \\
\text { legal status }\end{array}$ & 24 & 28 & 18 & 2 & 6 & 3.79 & 75.8 \\
\hline The overall average & 38.2 & 26.2 & 8.2 & 1.6 & 3.8 & 4.20 & 84 \\
\hline
\end{tabular}

\section{Reference :: the table prepared by the researcher}

Table No. (17) shows the views of the research sample in developing solutions to this crisis or mitigating its impact. The paragraphs that ranked first, second and third achieved a weighted average and a percentage weight higher than the general average and its percentage weight, which indicates that these solutions are direct to solve the crisis, where the first and most important solutions is to cleanse areas of displacement through the lifting of the military capabilities of the state and build conditions that encourage the return of the liberated areas, where this paragraph has achieved the highest weighted average as was(4.51) And weight percent(90.2)The solution

, which ranked second is the construction of housing units for displaced people away from military conflict zones to contribute to the alleviation of the crisis has made this paragraph, the average $\mathrm{i}$ - weighted(4.41) And 
weight percent(88.2)The paragraph on identifying an independent agency that is permanently responsible for all disasters in the country came in third place. This paragraph achieved a weighted average(4.24)And in percent weight(84.8) Either a paragraph, which occupied the t ranking fourth paragraph, which ranked fifth ranking was Mtostehma likely less than the overall average for this axis as well as the weight percentile where the weighted average of the two (4.03) and (3.79)And weight percent(80.6) and (75.8) Respectively, it shows that the urge to peaceful coexistence in light of reconciliation and acceptance among Iraqi groups is not solutions that have a direct impact in resolving the crisis as well as the request for international support and regional and urged the international community to help contain the crisis shows that it is not the solutions of direct and the reason is due to the lack of a framework Legal binds the international and regional community to contain the crisis.

\section{Conclusions and recommendations}

\section{Conclusions:}

1- The problem of displacement internal is one of the most dangerous manifestations facing Iraqi society, and the danger is to increase the flow and continuity and loss of state control over the containment of modernity for the Iraqi government institutions.

2-The study showed, through the data of the National Survey of the Central Bureau of Statistics and in cooperation with the Ministry of Immigration and Displacement, and through the data of the International Organization for Migration for the Displaced, that the most violent waves of displacement for the year 2014 from the western regions of Iraq came after the fall of Mosul at the hands of ISIS terrorist gangs and the transformation of the original areas of the displaced into battlefields. 
3- From the results of the study it became clear that the internal displacement of Iraq is a collective and Ikh r particular age group and for both sexes. It was found that the majority of the displaced were originally from three governorates ) Naynawa , Anbar, and Salah alDin), where the highest percentages of displaced families were recorded.

4- Through the study and research on the causes of the Iraqi internal displacement, it became clear that it came as a result of compelling security, political and sectarian reasons that were imposed on them and made them suffer in a tragic way, far from security stability.

6- Through the results of the study, it became clear that there is a lack of containment of the internal displacement crisis in Iraq and a weak government role, as well as the lack of seriousness of international organizations in dealing with this crisis in Iraq and the presence of corruption in managing the displaced file was a major reason for not controlling the crisis .It was found that the religious authorities have an acceptable role in providing aid to the internally displaced in Iraq

6- Internal displacement in Iraq has generated great suffering for the displaced, including political, economic, psychological, social, and health .It has become clear that displacement has a great impact on students leaving their studies for financial reasons primarily.

\section{Recommendations:}

1-Forming a permanent emergency authority for all crises and disasters expected to occur in the country and not a crisis cell, which is formed by the legislative authority as a supervisory role, and the executive authority is made up of service departments and local and international organizations, and this body has branches in the governorates that contain sections (economic, social, health, security, and administrative (And military).

2-The government should develop legislation and implement a national policy on internal displacement and request international and regional support to contain this crisis.He urged the international 
community to provide support to the internally displaced by strengthening their legal status.

3- Authorizing a body specialized in crisis management to manage and treat this crisis and reconsider the currently authorized body

4- Determining the identity of the displaced by issuing special cards for them for the purpose of nurturing them and distinguishing between them and the infiltrators of terrorists, and on the other hand, for the purpose of controlling the provision of services to them.

5- Allowing the space in front of the media for the purpose of media coverage of the displaced helps the state and other concerned parties to intervene in a timely manner to provide services to the displaced as quickly as possible.

6-Building conditions that encourage the voluntary return of displaced persons, especially after the liberated areas have been destroyed, and compensation for returnees whose properties have been damaged.

7- Greater importance must be given through conducting more studies to reveal the extent of the problem and the changes taking place in circumstances. These studies should seriously consider what is happening on the ground, avoiding bias towards a particular party or sect at the expense of the Iraqi displaced group and overlook their suffering.

8- On a no - governmental institutions to read and analyze the scene of political and security contexts and to reach results where the possibility of internal displacement for showing in areas of tension and conflict and how to handle and configuration of this phenomenon.

9- The government should develop social programs that work on the social construction of the country and reduce the bad social effects of displacement and urge peaceful coexistence in light of reconciliation and acceptance between all Iraqi parties and groups and make them feel one identity away from dispersion and difference.

\section{References :}


1. Aamir Moayed , 2014 "The delay in international support reflects its lack of seriousness in providing assistance ".Al-Alam Newspaper 1357

2. Abdul Wahid Mishaal Abd, 2012, "Iraqi community in Egypt " University of Baghdad, Journal of the College of Arts, No. 99, p. 668

3. Adnan Abu Zaid. 2014" The Iraqi Media Network mobilizes efforts to provide relief to the displaced ".The News Center of the Iraqi Media Network , 14 August.

4. Ali Jabbar Al-Faraihi, 2015 " A solution to the displaced people crisis in Iraq ".Al-Haqiqa Newspaper in Iraq, 12 January

5. Ammar Issa Karim .2009 " Internally displaced persons in light of international protection"An applied study on the displaced in Salah al-Din Governorate, Tikrit University, College of Law, Tikrit University Journal of Legal and Political Sciences, Volume 1, Issue 3,Pages188-214.

6. Balig Teslakian and Adnan Naseem. "Internally Displaced Persons: What Protection?" Amnesty International E-Journal /Regional Office for the Middle East and North Africa, p. 21 .https: // www. amnesty .org / en

7. Harm Muhammad Badawi and Abdul Azim Suleiman. 2014 " The Economic Impact of Displacement in Sudan ".Deanship of Scientific Research, Journal of Economic Sciences . Pp. 13, p. 38

8. Harm Muhammad Badawi and Abdul Azim Suleiman .Previous source, p. 43

9. Hussein Karim Al-Saadi. , 2009, Spatial analysis of forced immigration to Al-Kut .Wasit University, Journal of the College of Education.

10. Ibrahim Abdel Khaleq Raouf,2007 " A study of the brain drain phenomenon" Al-Mustansiriya University, p. 225

11. Jabbar Abdul Jbeil and Qais Majeed Alloush.2014 "Spatial variation in the phenomenon of internal forced migration in Iraq, 
except for the Kurdistan region "University of Babylon, College of Education for the Humanities.

12. Moataz Naim and Matanios Makhoul. 2015, "Analysis of the causes of internal migration in the Syrian Arab Republic"Damascus University, Damascus University Journal of Economic and Legal Sciences, Vol. 21, No. 1, P.140

13. Muhammad Adam Yusef and Salwa Muhammad. 2013" Program effectiveness Irshad myself in reducing aggressive behavior (pilot study of the children of the displaced camps of El Geneina local West Darfur state ".University of Sudan . Journal of the Humanities and Economics ,No. 1:, p. 167

14. Noor Khamis . 2009 "Internally displaced persons in Kenya "General Secretariat of the Economic ,Social and Cultural Council of the African Union, November,

15. Salim Maarouk and Hussein Qadri .2009 "Protecting refugees from armed conflict " Haji Lakhdar University .p.99

16. The International Organization for Migration in Iraq, (January :2013) Internal Displacement in Iraq: Barriers to Integration .

17. The International Organization for Migration., (April: 2015) Displacement Tracking Matrix, Round 18 Annex 2, p.15.

18. Ziyad bin Ali bin Mahmoud Al-Jarjawi . 2010 "Pedagogical methodological rules for building the questionnaire ",Al-Quds Open University Press Bin Jarrah, i 2, p100.

\section{The Appends}

\section{Appendix 1}

Arbitrators Committee

\begin{tabular}{|l|l|c||c|}
\hline $\mathrm{T}$ & Name Triple & $\begin{array}{c}\text { The } \\
\text { scientific }\end{array}$ & Workplace \\
\hline
\end{tabular}


University of Thi-Qar Journal

ISSN (print): 2706- 6908, ISSN (online): 2706-6894

Vol.15 No.2 June 2020

\begin{tabular}{|c|c|c|c|}
\hline & & title & \\
\hline 1 & $\begin{array}{l}\text { Dr..Yahya Abdul Redha } \\
\text { Abbas } \\
\end{array}$ & professor & $\begin{array}{c}\text { Dean of the Technical Institute / } \\
\text { Nazareth }\end{array}$ \\
\hline 2 & Dr ..Mwafak Abdel Aziz & professor & $\begin{array}{c}\text { Generating the } \mathrm{C} \text { at the Technical } \\
\text { Institute / Nasserism }\end{array}$ \\
\hline 3 & Dr ..Hussein Youssef & professor & $\begin{array}{c}\text { Generating the } \mathrm{C} \text { at the Technical } \\
\text { Institute / Nasserism }\end{array}$ \\
\hline 4 & Dr ..Rashid Hamid Mazyed & Teacher & $\begin{array}{c}\text { Generating the } \mathrm{C} \text { - college } \\
\text { technical administrative / Dhi Qar }\end{array}$ \\
\hline 5 & Younes fakher Odeh & Teacher & $\begin{array}{c}\text { Generating the } \mathrm{C} \text { at the Technical } \\
\text { Institute / Nasserism }\end{array}$ \\
\hline 6 & Ali Saleh Muhammad & office boss & $\begin{array}{l}\text { Dhi Qar Office - Ministry of } \\
\text { Immigration and Displacement }\end{array}$ \\
\hline
\end{tabular}

\section{Appendix 2}

\section{Questionnaire form}

Honorable brothers and sisters......

This questionnaire aims to obtain data for the purpose of studying the phenomenon of internal displacement in Iraq, to find out its causes, and to contribute to submitting some proposals, hoping that they will benefit decision-makers in resolving this crisis, so I would like to kindly answer all the paragraphs honestly, objectively and honestly by putting a tick (correct) in the appropriate column. From your point of view, noting that the data that will be obtained will be for scientific research purposes only .

researcher

General questions: 
University of Thi-Qar Journal

ISSN (print): 2706- 6908, ISSN (online): 2706-6894

Vol.15 No.2 June 2020

Academic Qualification: Workplace:

\begin{tabular}{|c|c|c|c|c|c|c|}
\hline $\mathrm{T}$ & Paragraph & $\begin{array}{l}\text { I } \\
\text { totally } \\
\text { agree }\end{array}$ & $\begin{array}{l}\text { I } \\
\text { agree }\end{array}$ & neutral & $\begin{array}{l}\text { I do not } \\
\text { agree } \\
\text { Strongly }\end{array}$ & $\begin{array}{l}\text { I do } \\
\text { not } \\
\text { agree }\end{array}$ \\
\hline 1 & $\begin{array}{l}\text { The phenomenon of displacement was } \\
\text { due to political reasons }\end{array}$ & & & & & \\
\hline 2 & $\begin{array}{l}\text { The security situation is one of the } \\
\text { reasons that led to the displacement }\end{array}$ & & & & & \\
\hline 3 & $\begin{array}{l}\text { Religious and ethnic beliefs are one of } \\
\text { the reasons for the displacement }\end{array}$ & & & & & \\
\hline 4 & $\begin{array}{l}\text { The economic side contributed as part } \\
\text { of the drivers of displacement }\end{array}$ & & & & & \\
\hline 5 & $\begin{array}{l}\text { There is a containment of the displaced } \\
\text { persons crisis by the relevant authorities }\end{array}$ & & & & & \\
\hline 6 & $\begin{array}{l}\text { The lack of seriousness of international } \\
\text { organizations in dealing with the } \\
\text { internally displaced in Irag }\end{array}$ & & & & & \\
\hline 7 & $\begin{array}{l}\text { Religious actors have a major role in } \\
\text { helping the internally displaced }\end{array}$ & & & & & \\
\hline 8 & $\begin{array}{l}\text { Civil society organizations in Iraq have } \\
\text { a role in helping the displaced }\end{array}$ & & & & & \\
\hline 9 & $\begin{array}{l}\text { Iraqi flags launch large calls for relief of } \\
\text { the displaced }\end{array}$ & & & & & \\
\hline 10 & $\begin{array}{l}\text { The presence of corruption in the } \\
\text { management of the displaced persons } \\
\text { file has led to the failure to control the } \\
\text { crisis }\end{array}$ & & & & & \\
\hline 11 & $\begin{array}{l}\text { The phenomenon of displacement } \\
\text { caused a loss of educational } \\
\text { opportunities for most of the students }\end{array}$ & & & & & \\
\hline 12 & $\begin{array}{l}\text { Housing arrangements for the } \\
\text { displaced do not meet the requirements } \\
\text { of protection or health services }\end{array}$ & & & & & \\
\hline
\end{tabular}


University of Thi-Qar Journal

ISSN (print): 2706- 6908, ISSN (online): 2706-6894

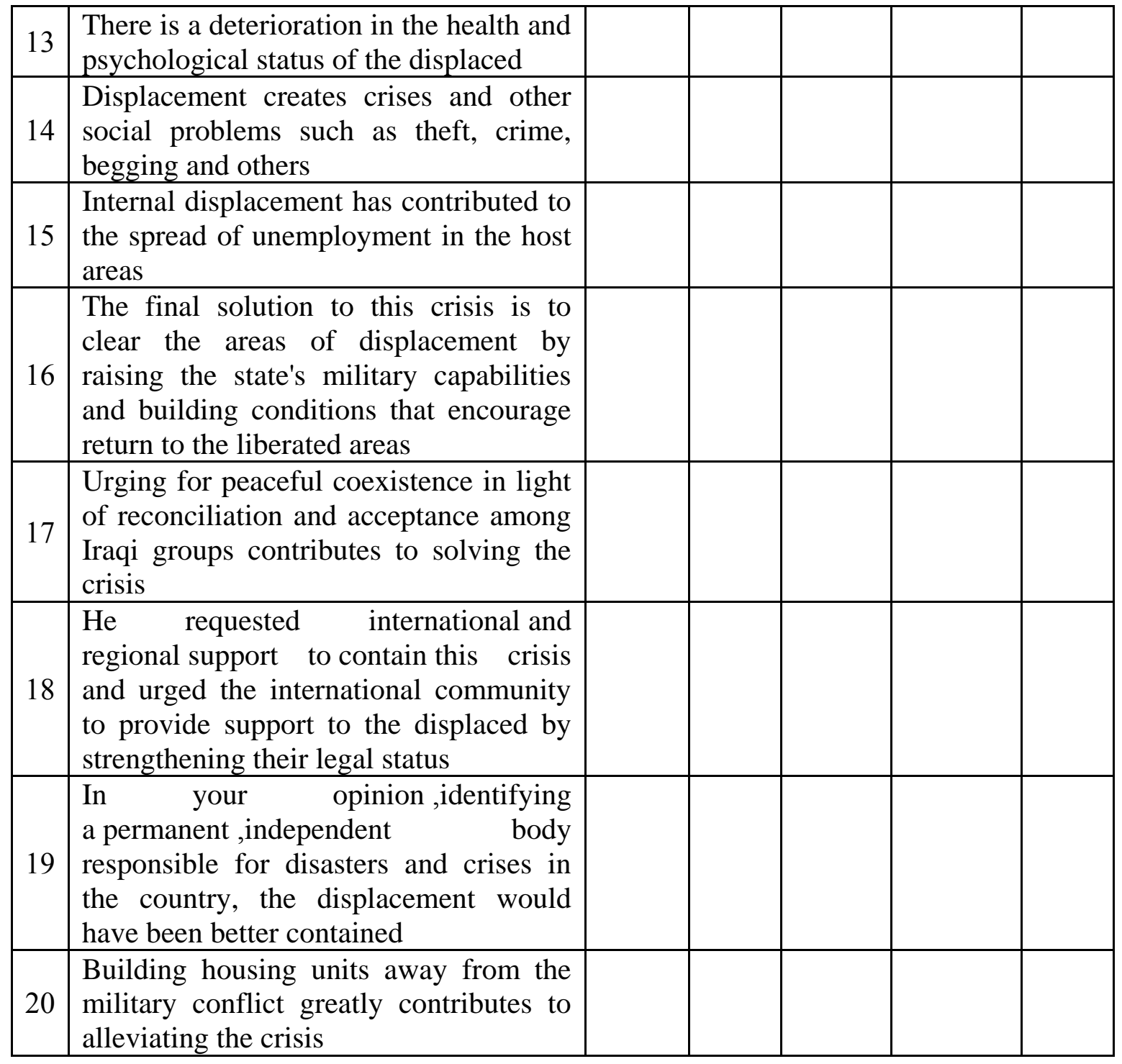

